\title{
Selection of breeds, strains and individual pigs for prolificacy
}

\author{
C. Legault \\ Institut National de la Recherche Agronomique, Station de Genetique quantitative et applique, \\ Domaine de Vilvert, 78350 Jouy-en-Josas, France
}

\begin{abstract}
Summary. Prolificacy, defined as litter size at birth, is currently considered to be the most important component of sow productivity. However, in spite of a spectacular increase in productivity due to management advances, litter size at birth has remained constant for the past 20 years. This situation seems to question the long-term efficiency of the classical methods of genetic improvement such as within-herd selection and crossbreeding between European or American breeds.

Some recent developments and research results suggest that one can be optimistic about the possibilities of increasing litter size in the near future. A survey of available breeds world-wide illustrates the important differences in average litter size (5-15 piglets), embryo mortality (15-40\%) and heterosis (ranging from 5 to over $30 \%$ ) on litter size. In particular the high prolificacy of some Chinese breeds can be used to speed up genetic progress in improving litter size either through systematic 3-way (3-4 additional piglets per litter in the $F_{1}$ compared with European breeds) or 4-way crosses with Western breeds, or by developing composite lines selected for heritable traits such as growth rate and backfat thickness. The efficiency of this system might be improved by combining Chinese breeds with 'hyperprolific' western strains. When using Chinese breeds, special attention should be paid to the choice of the terminal boar, which should be as lean as possible, in order to produce acceptable carcasses for sale.

Another potential solution would be to use modern computerized recording systems to detect extreme individuals and then to apply a strong selection intensity. Using this approach, it is then possible to develop a gene pool for prolificacy. Results obtained in France, Great Britain and Australia are encouraging. The expected progress is about 0.5 piglets per litter when strain selection is limited to one sex and about 1 piglet when it includes both sexes. Moreover, using crossbreeding, the heterosis effect seems to be cumulated with the genetic changes mentioned above. The computer can also be an aid in eliminating chromosomal translocations responsible for a reduction in prolificacy ranging from 5 to $50 \%$.
\end{abstract}

\section{Introduction}

Prolificacy, defined as litter size at birth, is considered to be the most important component of annual sow productivity measured as number of piglets weaned per sow and per year (Hill \& Webb, 1982; Legault, 1983). However, in spite of a spectacular increase in the productivity of sows during the past 10 years mainly as a result of advances in management (e.g. reduction in farrowing interval and pre-weaning mortality), litter size at birth has remained constant for the past 20 years (Noguera \& Legault, 1984). It is generally accepted that improving pig prolificacy, usually through within-herd selection, is difficult and has little prospect of success because of low heritabilities and the difficulity of applying a high selection pressure. On the other hand, crossbreeding is known to be the most rapid way of improving litter size within a limited period of time. It has also been well 
established that the improvement to be expected from crossbreeding is restricted by limitations imposed by the heterosis effect.

World pig populations exhibit considerable variation in litter size ranging from about 4.5 in French wild pigs (Aumaitre, Morvan, Quere, Peiniau \& Vallet, 1982) to about 15 in certain Chinese breeds (Legault \& Caritez, 1983; Zhang, Wu \& Rempel, 1983; Cheng, 1983). Such a difference of about 10 piglets indicates that genetic progress could be expected by taking advantage of the large between-breed variability (Dickerson, 1969) without neglecting the production traits represented by growth, feed efficiency and body composition.

Another solution would be to use modern computerized systems to detect extreme animals exhibiting prolificacy, then to apply a very strong selection intensity and to develop a gene pool for this trait (Legault \& Gruand, 1976; Tomes \& Newman, 1984; M. Bichard \& C. Tomkins, personal communication). The computer can also be used as an aid for eliminating abnormalities such as chromosomal translocations (Popescu, Bonneau, Tixier, Barhi \& Boscher, 1984).

The question of genetic improvement of litter size is receiving much attention in several countries and many reviews have recently been devoted to this subject (Johansson, 1981; Vangen, 1981; Hill \& Webb, 1982; Ollivier, 1982; Bolet \& Legault, 1982; van der Steen, 1983; Legault, 1983).

This paper will emphasize two approaches, namely, exploitation of the genetic betweenbreed variability with particular attention to European and Chinese breeds and development of hyperprolific strains by selection of extreme individuals in large populations.

\section{Variation amongst breeds}

The large litter size in some Chinese breeds of pigs (see Cheng, 1983, for a review) is also associated with early puberty and good mothering ability.

However, as the main goal of the pig industry is economic meat production our attention should be focussed on the balance between reduced production costs of the weaned piglet due to a better productivity of the dam and excellent growth and carcass performance in the slaughtered pig. This is the reason that the relative potential of breeds in terms of 'reproduction' and 'production' traits, as defined by Moav \& Hill (1966), will be used as the basis of this survey.

\section{Classification of breeds}

Recent surveys of pig breeds have been made by Hill \& Webb (1982) and Bolet (1985) for reproductive performance and by Sutherland, Webb \& King (1985) for growth and carcass traits. Sutherland et al. (1985) pointed out the difficulty of getting up-to-date comparisons for 'production' traits because the breeds involved could have changed over time by selection, genetic drift or incorporation of genes from other breeds. The situation is different for reproductive traits of low heritability, such as litter size at birth, which has remained fairly stable in most countries over the past decade (Skjervold, 1979; Johansson, 1981; Noguera \& Legault, 1984).

The number of identified pig breeds in the world is about 350 , most of which are native or local populations (Mason, 1969). However, there is not always a clear distinction between strains or varieties of the same breed. Here these breeds will be divided into four general categories based on their reproductive and productive potential.

Dual-purpose breeds. This group comprises a small number of breeds which are most generally used in intensive management systems, for example, Large White, Yorkshire and Danish Landrace and American breeds such as Chester White. It is also usual to include the Duroc in this category in Europe (Sellier, 1982) but in North America this breed is usually incorporated into terminal sire lines. The common characteristic of 'dual-purpose' breeds is to exhibit a satisfactory level of both reproduction and production traits. Puberty usually occurs between 190 and 240 days of age and average litter size varies within a relatively narrow range (10-11.5 at birth, 8-9.5 at weaning in good conditions), as reported by Hill \& Webb (1982). 
Breeds specialized in 'production'. This group includes a small number of breeds specially raised for producing boars for terminal crosses. It comprises European Pietrain and Belgian Landrace, American Hampshire and Poland China as well as an increasing number of pure strains or composite lines recently developed in several countries. Their general characteristics are a moderate prolificacy (8-10 piglets born and 6-8 piglets weaned per litter) and a high lean content in the carcass. Other desired qualities are libido, fertility and hardiness in boars as well as a good 'combining ability' with maternal lines leading to a large expression of heterosis on daily gain and food utilization. While 'dual purpose' breeds can be recommended for rotational crossbreeding schemes, the specialized sire breeds or lines are only convenient as terminals for 2-4-way crossbreeding schemes. The relatively low prolificacy of Pietrain and Belgian Landrace breeds which are both characterized by an extreme ham conformation ('double-muscle') can be explained partly by a high frequency of the halothane-sensitivity gene responsible for reduction of litter size by at least 1 unit (see Hill \& Webb, 1982; Ollivier \& Sellier, 1982; Cardent, Hill \& Webb, 1985, for reviews). As far as the Hampshire breed is concerned, females seem to have a lower ovulation rate and a higher embryonic mortality than their contemporaries of the Duroc and Yorkshire breeds (Young, Johnson \& Omtvedt, 1976).

Breeds specialized in 'reproduction' traits. This group, to which special attention is paid in this review, concerns essentially a limited number of native breeds from the People's Republic of China. In that country, where about one-third of the world pig population is raised, about 40 breeds of economic importance have been listed and they can be subdivided into more than 130 varieties (Zheng, 1981). A limited number of these native breeds or strains (probably less than 20) exhibit an exceptional ability for reproduction. Several reviews have been devoted to a survey of Chinese breeds: Phillips \& Hsu (1944); Epstein (1969); Legault (1978); Gianola, Legault \& Caritez (1982); Zhang et al. (1983); Cheng (1983). The main characteristics of the prolific breeds of China can be summarized as follows.

(1) A high prolificacy (13-17 pigs born per litter) and an excellent mothering ability as illustrated by the data in Table 1 (Zhang et al., 1983) for 5 Chinese breeds ( 4 from the Taihu group and 1 from Northern China). As shown in Table 2, these results have been confirmed in France (Legault \& Caritez, 1983) with Meishan females, both at birth and at weaning (14.5 and 13.5 pigs per litter respectively), but not with Jiaxing females (11.0 and 9.8 pigs born and weaned per litter

Table 1. Reproductive performance of four Taihu breeds and the Damin breed of Chinese pig (data from Zhang et al., 1983)

\begin{tabular}{|c|c|c|c|c|c|c|}
\hline \multirow{2}{*}{$\begin{array}{l}\text { Reproductive } \\
\text { performance }\end{array}$} & \multirow[b]{2}{*}{ Parity } & \multicolumn{4}{|c|}{ Taihu } & \multirow[b]{2}{*}{ Damin } \\
\hline & & Erhualian & Fenjing & Meishan & Jiaxing & \\
\hline \multicolumn{7}{|l|}{ No. of pigs born } \\
\hline \multirow[t]{2}{*}{ Total } & $1+2$ & $12 \cdot 4 \pm 4 \cdot 0$ & $14 \cdot 2 \pm 5 \cdot 2$ & $14 \cdot 0 \pm 4 \cdot 4$ & $12 \cdot 8 \pm 4 \cdot 7$ & $13 \cdot 2$ \\
\hline & $\geqslant 3$ & $\begin{array}{c}15 \cdot 3 \pm 5 \cdot 1 \\
(1278)\end{array}$ & $\begin{array}{c}17.0 \pm 6 \cdot 0 \\
(426)\end{array}$ & $\begin{array}{c}17 \cdot 0 \pm 4 \cdot 3 \\
(511)\end{array}$ & $\begin{array}{c}16 \cdot 9 \pm 4 \cdot 3 \\
(207)\end{array}$ & $\begin{array}{l}15 \cdot 5 \\
(104)\end{array}$ \\
\hline \multirow[t]{2}{*}{ Live } & $1+2$ & $\begin{array}{c}11 \cdot 5 \pm 3 \cdot 4 \\
(978)\end{array}$ & $\begin{array}{c}12 \cdot 8 \pm 4 \cdot 5 \\
(346)\end{array}$ & $\begin{array}{c}12.9 \pm 3.6 \\
(386)\end{array}$ & $\begin{array}{c}11 \cdot 9 \pm 3 \cdot 7 \\
(248)\end{array}$ & $\begin{array}{l}12.8 \\
(51)\end{array}$ \\
\hline & $\geqslant 3$ & $\begin{array}{c}13 \cdot 6 \pm 3 \cdot 8 \\
(1121)\end{array}$ & $\begin{array}{c}14.8 \pm 4 \cdot 4 \\
(426)\end{array}$ & $\begin{array}{c}14 \cdot 8 \pm 3 \cdot 6 \\
(511)\end{array}$ & $\begin{array}{l}14 \cdot 4 \pm 3 \cdot 4 \\
(207)\end{array}$ & $\begin{array}{l}14 \cdot 4 \\
(104)\end{array}$ \\
\hline \multirow[t]{2}{*}{ No. of pigs weaned } & $1+2$ & $\begin{array}{c}10 \cdot 0 \pm 3 \cdot 1 \\
(680)\end{array}$ & $\begin{array}{c}11 \cdot 7 \pm 4 \cdot 0 \\
(346)\end{array}$ & $\begin{array}{c}11 \cdot 3 \pm 3.6 \\
(386)\end{array}$ & $\begin{array}{c}9.9 \pm 3.6 \\
(248)\end{array}$ & $\begin{array}{c}10 \cdot 3 \\
(51)\end{array}$ \\
\hline & $\geqslant 3$ & $\begin{array}{c}11.5 \pm 3.7 \\
(864)\end{array}$ & $\begin{array}{c}12 \cdot 1 \pm 3 \cdot 2 \\
(426)\end{array}$ & $\begin{array}{c}12 \cdot 9 \pm 3 \cdot 0 \\
(511)\end{array}$ & $\begin{array}{c}12 \cdot 1 \pm 3 \cdot 2 \\
(207)\end{array}$ & $\begin{array}{l}11.0 \\
(104)\end{array}$ \\
\hline
\end{tabular}

Values are mean \pm s.d. for the no. of pigs in parentheses. 
Table 2. Least squares estimates of litter size resulting from different types of crosses between European and Chinese breeds in France (data from Legault et al., 1984)

\begin{tabular}{|c|c|c|c|c|}
\hline \multirow{2}{*}{$\begin{array}{l}\text { Genotype } \\
\text { of the dam }\end{array}$} & \multirow{2}{*}{$\begin{array}{l}\text { No. of } \\
\text { litters }\end{array}$} & \multicolumn{3}{|c|}{ No. of piglets/litter } \\
\hline & & Total & Born alive & Weaned \\
\hline LW and LF & 42 & $10 \cdot 7^{b}$ & $10 \cdot 2^{c}$ & $9 \cdot 2^{b}$ \\
\hline $\mathrm{MS}$ & 115 & $14 \cdot 9^{\mathrm{a}}$ & $14 \cdot 0^{\mathrm{ab}}$ & $13 \cdot 1^{2}$ \\
\hline$J X$ & 86 & $11 \cdot 6^{6}$ & $10 \cdot 8^{c}$ & $10 \cdot 0^{\mathrm{b}}$ \\
\hline $\mathrm{JH}$ & 31 & $11 \cdot 6^{b}$ & $|1 \cdot|^{\mathrm{c}}$ & $9 \cdot 9^{\mathrm{b}}$ \\
\hline $\mathrm{MS} \times \mathrm{JX}$ and $\mathrm{J} X \times \mathrm{MS}$ & 18 & $15 \cdot 8^{n}$ & $14 \cdot 7^{2}$ & $13 \cdot 4^{*}$ \\
\hline $\mathrm{MS} \times(\mathrm{LW}$ or $\mathrm{LF})$ & 107 & $15 \cdot 3^{a}$ & $14 \cdot 5^{2}$ & $12 \cdot 8^{a}$ \\
\hline $\mathrm{JX} \times(\mathrm{LW}$ or LF $)$ & 68 & $15 \cdot 2^{a}$ & $14 \cdot 7^{2}$ & $13 \cdot 2^{a}$ \\
\hline JH (LW or LF) & 27 & $11 \cdot 7^{b}$ & $11 \cdot 4^{\mathrm{bc}}$ & $9 \cdot 7^{b}$ \\
\hline LW $\left(\frac{1}{2} M S\right.$ or $\left.\frac{1}{2} J X\right)$ & 63 & $11 \cdot 5^{6}$ & $10 \cdot 8^{\mathrm{c}}$ & $9 \cdot 9^{b}$ \\
\hline Total & 557 & & & \\
\hline Means & & 13.5 & $12 \cdot 8$ & $11 \cdot 6$ \\
\hline
\end{tabular}

LW = Large White; MS = Meishan; LF = French Landrace; JX = Jiaxing; $\mathrm{JH}=$ Jinhua.

Significant differences $(P<0.05)$ between genotypes are indicated by different letters.

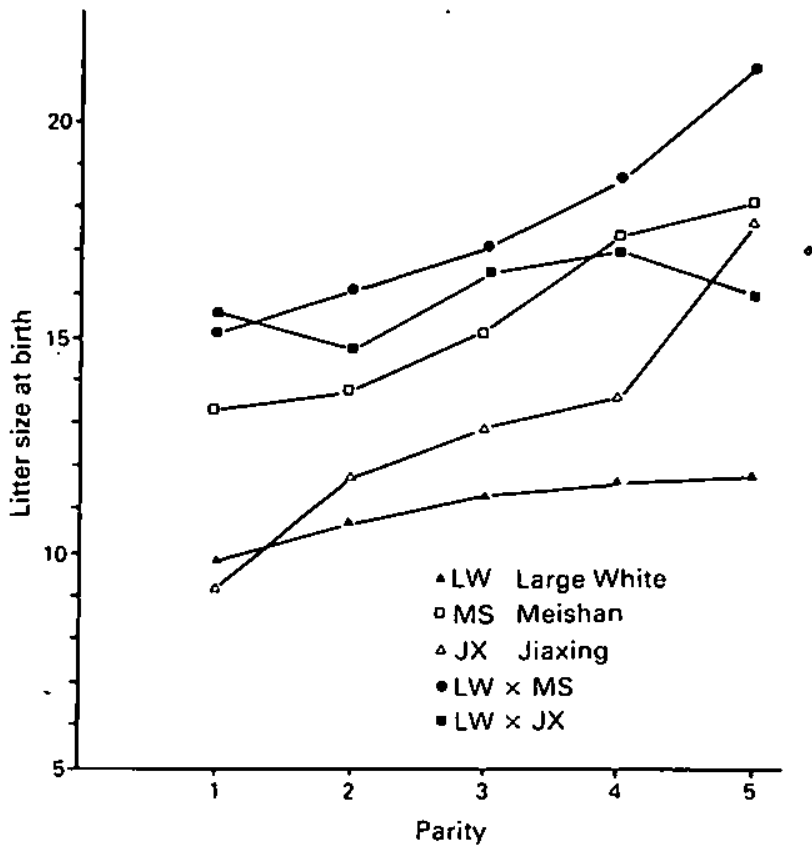

Fig. 1. Comparative variation of litter size at birth according to parity in Large White (LW), Meishan (MS), Jiaxing (JX), $F_{1}(L W \times M S$ and $L W \times J X)$ sows (J. C. Caritex \& C. Legault, unpublished). 
respectively). However, recent data (J. C. Caritez \& C. Legault, unpublished results) seem to indicate that Jiaxing females reach a high prolificacy level beyond the fourth parity (Fig. 1).

(2) Puberty is attained between 2 and 4 months of age in the Taihu group (Cheng, 1983). This early maturation was confirmed for Meishan and Jiaxing gilts at 82 and 88 days in western management conditions (Legault \& Caritez, 1983).

(3) Growth rate and mature size are low. For example $80 \mathrm{~kg}$ body weight is reached at 8 months of age in China and at 6 months in France while the adult body weight of females is about $170-210 \mathrm{~kg}$ in these two environments respectively.

(4) Carcasses are very fat and the conformation is poor. On the basis of recent results obtained in France (Legault, Sellier, Caritez, Dando \& Gruand, 1985), the lean content in whole carcasses of Meishan and Jiaxing sows would be 16-18\% lower than in European Large White and Danish Landrace.

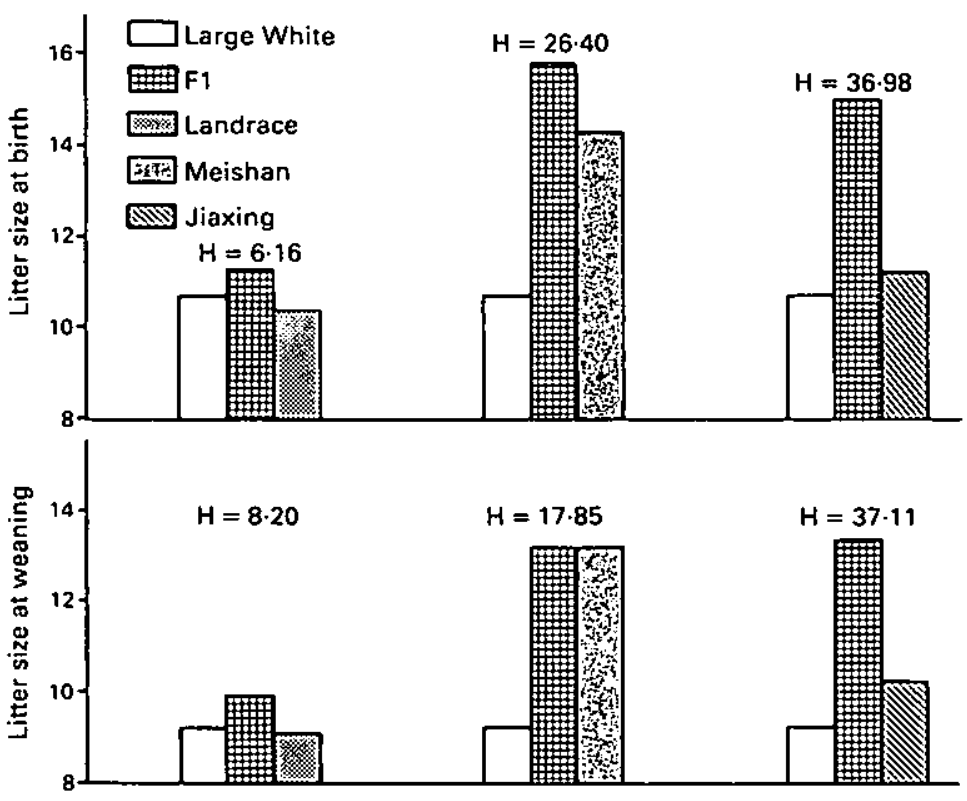

Fig. 2. Variation in maternal heterosis $(\mathrm{H})$ effects on litter size at birth and at weaning when Large White is crossed with French Landrace, Meishan or Jiaxing breeds (J. C. Caritez \& C. Legault, unpublished).

The results of the French experiment on prolificacy of $F_{1}$ females obtained by crossing 3 Chinese breeds (Meishan, Jiaxing and Jinhua) with 2 European breeds (Large White and Landrace) are summarized in Table 2 (Legault \& Caritez, 1983; Legault, Caritez, Gruand \& Bidanel, 1984). Prolificacy of $F_{1}$ Meishan and $F_{1}$ Jiaxing females is slightly but not significantly higher than in pure Meishan shows (15.1 and 14.8 piglets born per litter respectively). This high prolificacy is accompanied by an excellent mothering ability (12.7 and 13 piglets weaned per litter respectively). The numerical productivity of these $\mathrm{F}_{1}$ sows is about $30 \%$ higher than that of contemporary European sows. This corresponds to 5-9 additional pigs weaned per sow per year. These findings are confirmed by the unpublished data shown in Fig. 2. Comparison of reciprocal crosses between Meishan and Jiaxing and European breeds suggests that subsequent prolificacy of $F_{1}$ females raised in $F_{1}$ large litters is not compromised. This could justify the use of purebred Chinese breeds 
as maternal lines to reduce the production cost of $F_{1}$ gilts. It should also be mentioned that the first oestrus of $F_{1}$ Chinese gilts occurs between 90 and 130 days of age. Without mating gilts at puberty, this early maturity could reasonably lead to a reduction of age at first farrowing by at least 1 month.

Local breeds. This group, whose common feature is to be well adapted to extremely varied and generally unfavourable conditions, contains the largest number of breeds and varieties (over 300 ). Both reproduction and production are usually low, the most useful characteristic being hardiness leading to a good resistance to various stresses, such as undernutrition, climate, diseases and parasites. These local breeds are often highly appreciated as maternal components of crossbreeding schemes adapted to extensive management systems.

\section{Variability of ovulation rate, embryonic survival and heterosis effect}

Comparisons between breeds or crosses involving the genotypes of the dam, the sire and the embryos require four types of parameters, i.e. mean effect of pure breeds, individual or direct heterosis effect on crossbred embryos, maternal and paternal heterosis effects due to use of crossbred females or males (Dickerson, 1969). As pointed out by Bolet (1985) with comparisons often being made between breeds with different ovulation rates, it is important to take into account the effect of ovulation rate on embryo mortality in order to estimate the specific uterine efficiency effect of the breed. Ovulation rate varies from 5.5 in French wild pigs (Aumaitre et al., 1982) to over 20 and embryo mortality from 13 to $40 \%$ (see Bolet, 1985). Moreover, there is no stable relationship between these two parameters. Wild sows and Meishan sows in France (unpublished data; Table 3) showed the same low embryo mortality (13-16\%) while ovulation rate was three times higher in the latter. A prolificacy similar to that of Meishan is obtained in the hyperprolific Large White strain (described below) in spite of an embryonic mortality of $40 \%$ (Table 3). Conversely, in another prolific Chinese breed (Jiaxing), ovulation rate and embryo mortality seem to be high (Rombauts, Mazzari \& du Mesnil du Buisson, 1982). Amongst the main European breeds, ovulation rate and embryo mortality seem to be significantly higher in Large White than in Landrace gilts (Legault \& Gruand, 1981). Amongst American breeds Hampshire gilts seem to have a lower ovulation rate and a higher embryo mortality than do Yorkshire and Duroc breeds (Young et al., 1976). However, much attention should be paid to parity and environment. For example, sows generally have a higher ovulation rate and embryo survival than gilts (see Legault, 1983, for review). On the other hand, the results of Cheng (1983) seem to indicate that embryo mortality in Meishan females is higher under Chinese than under French environmental conditions.

Table 3. Comparison of ovulation rate and embryo mortality between control Large White, 'hyperprolific' Large White and Meishan sows (unpublished data)

\begin{tabular}{|c|c|c|c|c|c|}
\hline Genotype & & $\begin{array}{l}\text { Ovulation } \\
\text { rate }\end{array}$ & $\begin{array}{l}\text { Litter } \\
\text { size }\end{array}$ & $\begin{array}{l}\text { No. of lost } \\
\text { embryos }\end{array}$ & $\begin{array}{c}\text { Embryo } \\
\text { mortality } \\
(\%)\end{array}$ \\
\hline $\begin{array}{l}\text { Control } \\
\text { Large White }\end{array}$ & & $\begin{array}{c}17.62 \pm 0.81^{\circ} \\
(20)\end{array}$ & $\begin{array}{c}12 \cdot 11 \pm 1 \cdot 11^{\circ} \\
(13)\end{array}$ & $\begin{array}{c}4 \cdot 83 \pm 1 \cdot 47^{2} \\
(13)\end{array}$ & $26 \cdot 0 \pm 6 \cdot 7^{\prime \prime}$ \\
\hline $\begin{array}{l}\text { 'Hyperprolific' } \\
\text { Large White }\end{array}$ & · & $\begin{array}{c}22.90 \pm 0.96^{b} \\
(25)\end{array}$ & $\begin{array}{c}13 \cdot 07 \pm 1 \cdot 33^{\circ} \\
(17)\end{array}$ & $\begin{array}{c}10 \cdot 62 \pm 1 \cdot 56^{b} \\
(17)\end{array}$ & $40 \cdot 9 \pm 7 \cdot 1^{2}$ \\
\hline Meishan & & $\begin{array}{c}17 \cdot 20 \pm 1 \cdot 20^{2} \\
(16)\end{array}$ & $\begin{array}{c}15 \cdot 73 \pm 1.54^{4} \\
(16)\end{array}$ & $\begin{array}{l}2 \cdot 40 \pm 1 \cdot 23^{a} \\
(16)\end{array}$ & $15.8 \pm 8.8^{\circ}$ \\
\hline
\end{tabular}

Values are mean \pm s.d. for the number of observations in parentheses.

Different letters indicatc significant differences $(P<0.05)$ between estimates. 
Sellier (1976, 1982) and Johnson (1981) have published reviews on individual and maternal heterosis effects on reproductive traits. The heterosis effect on ovulation rate appears to be low $(0 \cdot 1-3 \%)$. Heterosis effects on litter size at birth are larger, i.e. the individual heterosis ranges from 2 to $5 \%$ while the maternal heterosis ranges from 7 to $10 \%$. Conversely, the paternal heterosis effect on litter size seems to be of low magnitude (Sellier, 1982). Consequently, the increase in prolificacy by crossbreeding seems to be due to a better survival of embryos of $F_{1}$ females rather than to a higher ovulation rate.

However, heterosis value may vary according to maternal and paternal breed combinations; it is relatively low between Large White and Landrace breeds (Sellier, 1982) but for litter size can be much higher when Chinese breeds are involved. As illustrated by Fig. 2, maternal heterosis may reach $26 \%$ in Meishan $\times$ European $F_{1}$ females and the exceptional value of $37 \%$ in Jiaxing $\times$ European $F_{1}$. Before becoming generally accepted, these preliminary estimates need to be confirmed on larger samples of animals and in appropriate crossing programmes.

\section{The hyperprolific strain}

Ollivier \& Bolet (1981) partly explained the failure of their selection experiment on prolificacy by lack of the possibility of reaching the expected selection intensity in a closed herd. Another potential solution based on a modern computerized field recording system has been presented and discussed by Legault \& Gruand (1976). By screening very large populations to detect exceptionally prolific sows, this method allows the application of a very strong selection pressure which can usually range from 0.3 to $3 \%$.

\section{Theoretical aspects}

The efficiency of such a system depends on the size of the population screened and also on the estimator of prolificacy under field conditions. Hence the extensive French recording system described by Legault, Molenat, Steier, Texier \& Zickler (1974) presently controls about $39 \%$ of the sow population (over 880000 litters in 1984). Litter size at birth (piglets born alive) is adjusted for parity effect, and the breeding value of sows is estimated on the basis of a within-herd contemporary comparison according to the formula:

$$
\Delta \mathrm{G}=\frac{n h^{2}}{1+(n-1) r} \Delta \mathrm{P}
$$

where $\Delta G$ is the breeding value of the sow expressed as deviation from the herd-contemporary mean, $\Delta \mathrm{P}$ is the corresponding phenotypic deviation observed on $n$ parities, and $h^{2}$ and $r$ represent heritability $(0 \cdot 10)$ and repeatability $(0 \cdot 15)$ of litter size respectively.

As illustrated in Table 4, the genetic superiority of a prolific sow is 1 piglet when its phenotypic superiority has averaged 4 units over at least 4 litters. The upper tail of the distribution of genetic merit (G) of 2210 prolific sows selected from a basic population of 378126 females is represented in Fig. 3.

The method itself consists of selecting boars from the progeny of dams with extreme prolificacy and then backcrossing these boars to sows with a similar extreme prolificacy. By repeating this type of backcross several times, the average genetic merit for prolificacy of boars progressively reaches the genetic level of the prolific sows used in each generation. The different possibilities of taking advantage of the 'hyperprolific' strains with a supposed genetic superiority equivalent to 1.2 piglets per litter in the pig industry are illustrated in Fig. 4. When the scheme is limited to prolific boars generally used in artificial insemination, the expected superiority of their daughters obtained with dams of the base population is nearly 0.5 piglets per litter after 5 years (the generation interval from 
Table 4. Breeding superiority $(\Delta G)$ of prolific sows in terms of the within-herd phenotypic superiority $(\Delta \mathrm{P})$ for various numbers of parties registered

\begin{tabular}{lccccc}
\hline \multicolumn{5}{c}{ Number of parities } \\
\cline { 2 - 6 }$\Delta \mathrm{P}$ & 1 & 2 & 3 & 4 & 5 \\
\hline 2 & 0.20 & 0.35 & 0.46 & 0.55 & 0.63 \\
4 & 0.40 & 0.70 & 0.90 & 1.10 & 1.25 \\
6 & 0.60 & 1.04 & 1.39 & 1.66 & 1.85 \\
\hline
\end{tabular}

$\Delta \mathrm{P}=$ within-herd phenotypic superiority for litter size.

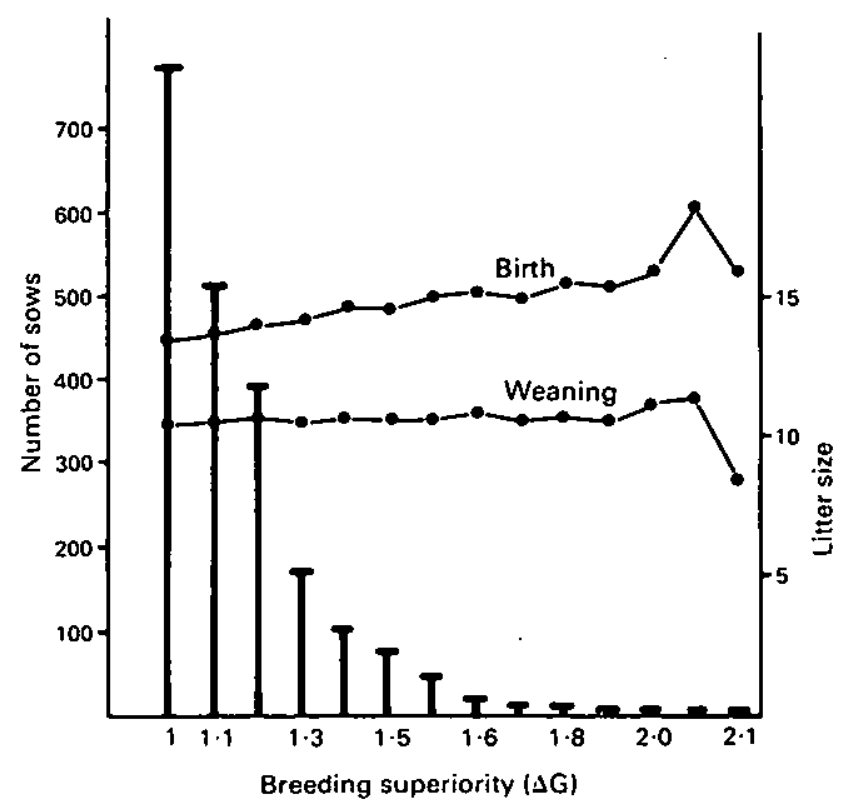

Fig. 3. Upper tail of the distribution of the breeding value (piglets born alive/litter) of 2210 prolific sows screened over a population of 378126 females.

sire to son being assumed to be 1 year). Assuming that this advantage can be cumulated with a heterosis effect, the expected gain can be near 1.3 piglets per litter in $F_{1}$ females obtained by crossing these boars with normal sows of another breed.

The second possibility is to include both sexes of the prolific strain. The main difficulty is the health risk due to the necessity of gathering breeding animals of very different origins. For this reason, it seems preferable to use females from a closed herd systematically inseminated with boars of a prolific line; this alternative supposes that the prolific strain of boars already exists in A.l. centres. It is then possible to visualize a closed herd of sows open through A.I. to a prolific strain of boars open itself to the whole pig population. Under these conditions, the expected gain in prolificacy is nearly 1 piglet per litter in pure strains and near 1.8 in the $F_{1}$ obtained by crossing two prolific strains from two different breeds. 


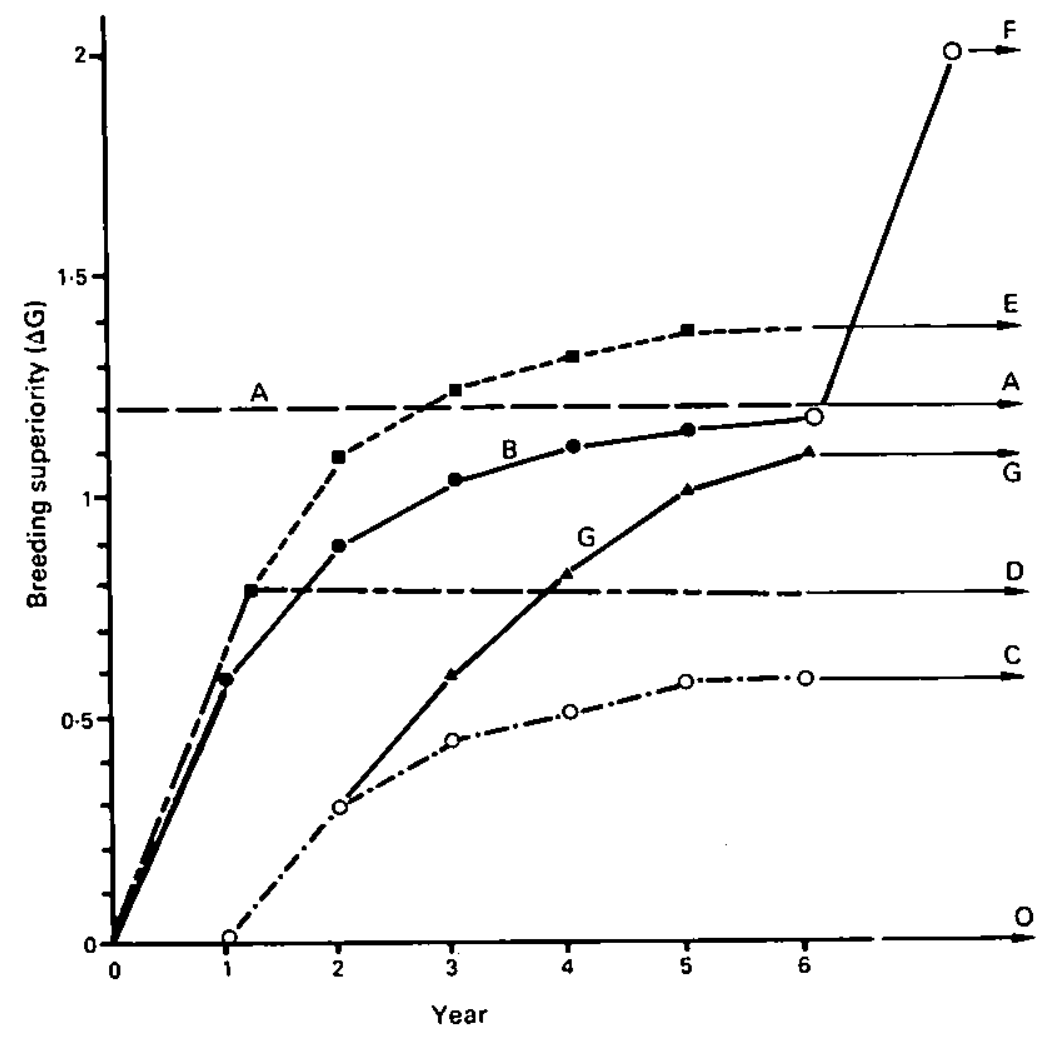

Fig. 4. Theoretical variations in litter size at birth in pure breeding and crossbreeding, with or without use of 'hyperprolific' strain pigs. A, breeding value of 'hyperprolific' sows; B, breeding value of sons of $A ; C$, breeding value of granddaughters of $A ; D$, crossbreeding without selection; E, crossbreeding using B boars; F, crossbreeding between hyperprolific strains of two different breeds; $G$, average genetic value in a herd systematically inseminated by $B$ boars; $O$, purebred base.

\section{Experimental and field results}

The first 'hyperprolific' sows were detected in 1973 in France and, from then on, 10 generations of Large White boars were selected according to the scheme described above so that their genetic superiority can presently be considered as stabilized at about $1-1 \cdot 2$ piglets per litter above the base population. The results so far obtained have been discussed by Legault, Gruand \& Bolet (1981), Bolet \& Legault (1982) and Legault (1983). These boars are used through A.I. with normal sows of the same breed or from the Landrace breed so that the improvement of prolificacy in their daughters only represents half their breeding superiority. As shown in Table 5 (experimental results), a significant increase in ovulation rate of 1.8 in gilts and 1.6 in sows over the control line is observed. The number of embryos alive on Day 30 of gestation was only 0.1 higher in pure gilts but 1.0 higher in pure sows and 0.8 higher in crossbred gilts. Also, on a sample of limited data, the number of piglets born increased in the second, but not in the first parity. A field comparison including Large White contemporaries, grand-daughters of the prolific boars and normal sows $\left(\frac{1}{4}\right.$ hyperprolific) and daughters of the same boars and normal sows ( $\frac{1}{2}$ hyperprolific) and daughters of these boars and prolific sows (completely hyperprolific) has been made (J. Gruand \& C. Legault, unpublished data). As shown in Table 6 , the gain in litter size over the control sows was $0 \cdot 33,0.65$ 
and 0.71 piglets respectively for the 3 genotypes, the only significant difference $(P<0.05)$ being observed between control and $\frac{1}{2}$ hyperprolific sows. The lack of difference in prolificacy between the daughters of normal ( $\frac{1}{2}$ hyperprolific) and hyperprolific sows may be partly due to negative maternal effects on litter size, the latter gilts being raised in large litters.

The increase in embryo mortality observed in gilts of the prolific strain (Table 5) was confirmed in a limited sample of hyperprolific sows directly bought from pig farmers to be compared with control Large White and Meishan sows (G. Bolet, F. Martinat-Botte, F. Locatelli \& A. Gruand, unpublished data). As shown in Table 3, the high prolificacy of these females seems to be due to a significantly higher ovulation rate (22.9 vs 17.6 in control and 17.2 in Meishan) followed by a higher embryo mortality (40.9 vs 26.0 and $15.8 \%$ respectively). In other words, 'hyperprolificacy' in European breeds would be essentially due to better ovarian activity and not to a better uterine carrying capacity.

A very similar method was applied within Great Britain (M. Bichard, unpublished data; Bichard \& David, 1985). Both sexes of 2 prolific strains have been developed since 1977 in two breeds (Large White and Landrace) by selecting exceptional individuals from the multipliers of the

Table 5. Litter size (piglets/litter) and its components in the progeny of 'hyperprolific' sows (no. in parentheses)

\begin{tabular}{|c|c|c|c|c|c|c|}
\hline \multirow[b]{2}{*}{ Group* } & \multicolumn{2}{|c|}{ Ovulation rate } & \multicolumn{2}{|c|}{$\begin{array}{l}\text { Surviving embryos } \\
\text { (30 days) }\end{array}$} & \multicolumn{2}{|c|}{ Litter size at birth } \\
\hline & Parity 1 & Parity 3 & Parity I & Parity 3 & Parity 1 & Parity 2 \\
\hline $\mathrm{H}_{1}$ & $\begin{array}{r}16 \cdot 3 \\
(87)\end{array}$ & $\begin{array}{l}18 \cdot 0 \\
(27)\end{array}$ & $\begin{array}{c}9 \cdot 6 \\
(60)\end{array}$ & $\begin{array}{l}14 \cdot 0 \\
(23)\end{array}$ & $\begin{array}{l}9 \cdot 6 \\
(42)\end{array}$ & $\begin{array}{l}11 \cdot 3 \\
(36)\end{array}$ \\
\hline $\mathrm{H}_{2}$ & $\begin{array}{r}15 \cdot 4 \\
(7)\end{array}$ & - & $\begin{array}{l}11 \cdot 2 \\
(60)\end{array}$ & - & - & - \\
\hline$C_{1}$ & $\begin{array}{l}14 \cdot 5 \\
(212)\end{array}$ & $\begin{array}{l}16 \cdot 5 \\
(93)\end{array}$ & $\begin{array}{r}9 \cdot 5 \\
(137)\end{array}$ & $\begin{array}{l}12 \cdot 5 \\
(83)\end{array}$ & $\begin{array}{c}10 \cdot 1 \\
(228)\end{array}$ & $\begin{array}{l}10 \cdot 6 \\
(199)\end{array}$ \\
\hline$C_{2}$ & $\begin{array}{c}5.2 \\
(104)\end{array}$ & - & $\begin{array}{c}10 \cdot 4 \\
(75)\end{array}$ & - & - & - \\
\hline
\end{tabular}

$H_{1}=$ progeny of hyperprolific boars in purebreeding; $\mathrm{H}_{2}=$ progeny of hyperprolific boars in crossbreeding; $\mathrm{C}_{1}=$ progeny of contemporaries in purebreeding (control); $\mathrm{C}_{2}=$ progeny of contemporaries in crossbreeding (control).

Table 6. Field comparison of size of litters farrowed by granddaughters and daughters (Large White breed) of boars of the 'hyperprolific' strain (J. Gruand \& C. Legault, unpublished)

\begin{tabular}{|c|c|c|c|c|}
\hline & \multicolumn{2}{|c|}{ Control Large White boars } & \multicolumn{2}{|c|}{$\begin{array}{l}\text { Large White boars of the } \\
\text { 'hyperprolific' strain }\end{array}$} \\
\hline & $\begin{array}{l}\text { Control } \\
\text { dams }\end{array}$ & $\begin{array}{c}\text { Half } \\
\text { hyperprolific } \\
\text { dams }\end{array}$ & $\begin{array}{l}\text { Control } \\
\text { dams }\end{array}$ & $\begin{array}{l}\text { Hyperprolific } \\
\text { dams }\end{array}$ \\
\hline $\begin{array}{l}\text { No. of litters } \\
\text { recorded }\end{array}$ & 1715 & 133 & 229 & 59 \\
\hline $\begin{array}{l}\text { Estimates of } \\
\text { litter size }\end{array}$ & $10.41 \pm 0.08^{n}$ & $10.74 \pm 0.31^{\mathrm{ab}}$ & $11.06 \pm 0.24^{b}$ & $10.84 \pm 0.54^{\mathrm{ab}}$ \\
\hline
\end{tabular}

Significant differences $(P<0.05)$ are indicated by different letters. 
Table 7. Comparison of reproductive data from purebred 'prolific' and control females (M. Bichard, unpublished data)

\begin{tabular}{|c|c|c|c|c|c|c|}
\hline & \multicolumn{3}{|c|}{$1981-1982$} & \multicolumn{3}{|c|}{$1983-1984$} \\
\hline & \multirow{2}{*}{$\begin{array}{l}\text { No. of } \\
\text { litters }\end{array}$} & \multicolumn{2}{|c|}{ Litter size } & \multirow{2}{*}{$\begin{array}{l}\text { No. of } \\
\text { litters }\end{array}$} & \multicolumn{2}{|c|}{ Litter size } \\
\hline & & Total & Born alive & & Total & Born alive \\
\hline $\begin{array}{l}\text { Pure Large W } \\
\text { Prolific } \\
\text { Control } \\
\text { Difference }\end{array}$ & $\begin{array}{l}171 \\
921\end{array}$ & $\begin{array}{r}10.9 \\
10.6 \\
+0.3\end{array}$ & $\begin{array}{r}10.0 \\
9.6 \\
+0.4\end{array}$ & $\begin{array}{r}1015 \\
717\end{array}$ & $\begin{array}{r}11.5 \\
10.6 \\
+0.9\end{array}$ & $\begin{array}{r}10.4 \\
9.8 \\
+0.6\end{array}$ \\
\hline $\begin{array}{l}\text { Pure Landrac } \\
\text { Prolific } \\
\text { Control } \\
\text { Difference }\end{array}$ & $\begin{array}{l}129 \\
717\end{array}$ & $\begin{array}{r}10.6 \\
10.4 \\
+0.2\end{array}$ & $\begin{array}{r}10.1 \\
9.7 \\
+0.4\end{array}$ & $\begin{array}{l}297 \\
611\end{array}$ & $\begin{array}{c}11.0 \\
11.0 \\
0\end{array}$ & $\begin{array}{r}10.3 \\
10.2 \\
+0.1\end{array}$ \\
\hline $\begin{array}{l}F_{1} \text { Large Wh } \\
\text { Prolific } \\
\text { Control } \\
\text { Difference }\end{array}$ & $\begin{array}{l}82 \\
73\end{array}$ & $\begin{array}{r}11.8 \\
10.6 \\
+1.2\end{array}$ & $\begin{array}{r}11.1 \\
10.3 \\
+0.8\end{array}$ & & & \\
\hline $\begin{array}{l}F_{1} \text { Landrace } \\
\text { Prolific } \\
\text { Control } \\
\text { Difference }\end{array}$ & $\begin{array}{l}66 \\
52\end{array}$ & $\begin{array}{r}10.9 \\
10.4 \\
+0.5\end{array}$ & $\begin{array}{r}10.6 \\
9.9 \\
+0.7\end{array}$ & & & \\
\hline
\end{tabular}

Table 8. Summary of litter sizes in field comparison on $\mathbf{I 4}$ farms of $F_{1}$ sows produced from 'prolific' or 'control' lines (M. Bichard, unpublished data)

\begin{tabular}{|c|c|c|c|c|}
\hline & & $\begin{array}{l}\text { Prolific } \\
\text { line }\end{array}$ & $\begin{array}{c}\text { Control } \\
\text { line }\end{array}$ & $\begin{array}{c}\text { Weighted mean } \\
\text { difference and } \\
\text { s.e. }\end{array}$ \\
\hline Ist litters & $\begin{array}{l}\text { No. of of farrowed } \\
\text { Mean no. of young born } \\
\text { Total } \\
\text { Alive }\end{array}$ & $\begin{array}{l}311 \\
11 \cdot 13 \\
10 \cdot 39\end{array}$ & $\begin{array}{r}10.47 \\
9.83\end{array}$ & $\begin{array}{l}+0.68 \pm 0.24 \\
+0.55 \pm 0.25\end{array}$ \\
\hline 2nd litters & $\begin{array}{l}\text { No. of } \$ 9 \text { farrowed } \\
\text { Mean no. of young born } \\
\text { Total } \\
\text { Alive }\end{array}$ & $\begin{array}{l}249 \\
11 \cdot 43 \\
10.89\end{array}$ & $\begin{array}{l}10.58 \\
10.07\end{array}$ & $\begin{array}{l}+0.88 \pm 0.38 \\
+0.84 \pm 0.30\end{array}$ \\
\hline 3rd litters & $\begin{array}{l}\text { No. of } 99 \text { farrowed } \\
\text { Mean no. of young born } \\
\text { Total } \\
\text { Alive }\end{array}$ & $\begin{array}{l}214 \\
12 \cdot 65 \\
12 \cdot 01\end{array}$ & $\begin{array}{l}12 \cdot 11 \\
11 \cdot 38\end{array}$ & $\begin{array}{l}+0.62 \pm 0.32 \\
+0.73 \pm 0.30\end{array}$ \\
\hline 4th litters & $\begin{array}{l}\text { No. of } \$ Q \text { farrowed } \\
\text { Mean no. of young born } \\
\text { Tolal } \\
\text { Alive }\end{array}$ & $\begin{array}{l}175 \\
13 \cdot 22 \\
12 \cdot 41\end{array}$ & $\begin{array}{l}123 \\
12.60 \\
11.62\end{array}$ & $\begin{array}{l}+0.76 \pm 0.35 \\
+0.96 \pm 0.34\end{array}$ \\
\hline
\end{tabular}

Pig Improvement Company. Table 7 gives up-to-date results of litter size from purebred females and mainly purebred litters, but including a few $F_{1}$ litters. The size of purebred litters is larger in the prolific than in the control strain. However, this difference seems to be greater in Large Whites $\left(0.3-0.9\right.$ extra piglets) than in Landrace (0-0.2 extra piglets). In the case of $F_{1}$ litters, this advantage is 1.2 piglets in Large White and 0.5 piglets in Landrace sows. Table 8 gives a summary of litter size, in field comparisons on 14 farms, of $F_{1}$ sows produced from prolific or control strains. The. results 
are much more homogeneous and indicate an advantage in favour of $F_{1}$ sows from the prolific line, ranging from 0.55 to 0.96 piglets per litter with each parity.

Another similar project combined with a selection experiment for prolificacy was performed in Australia (Tomes \& Newman, 1984; Tomes \& Nielsen, 1985). Intensive piggeries were screened for breeding stock originating from litters with at least 16 piglets. Since 1977,100 boars and 200 gilts have been obtained. First litters were standardized to 8 sucking piglets and the replacement gilts were selected from first litters when the total number for the first and second litters exceeded 25 piglets. Boars were selected from litters exceeding 16 or 27 piglets in the first two litters. After 3 generations of selection, average first litter size was 11.47 compared with $10 \cdot 14$ for the controls and for the second litter size 12.91 vs 10.86 respectively. The authors also observed a tendency for an improvement of weaning-conception interval, conception rate and scrotal area in the selected line.

Results obtained in France, Great Britain and Australia seem to indicate that within-population selection for extreme individuals is a relatively efficient method of increasing litter size by $0.5-1$ piglets in less than 5 years and that this gain can be cumulated with heterosis by crossbreeding. However, the method requires some comments and criticisms.

(a) The range of progress is relatively limited (about 1 piglet per litter) unless intensive selection continues to be applied to the prolific strain. The results obtained in Australia unfortunately were limited to 3 generations but are very encouraging. Another problem is to choose between a closed strain and a real 'prolific gene pool' partly open to exceptional animals from the outside population.

(b) Performance of extreme individuals can be due to non-transmissible favourable gene interactions, mostly when the screening is not limited to pure breeds.

(c) Prolific strains including both sexes face two difficulties, namely, the health risk and the maternal effects influencing gilts raised in large litters (Robison, 1981; van der Steen, 1983). These two difficulties are overcome when the strain is limited to boars used in A.I.

(d) Extensive field screening is only possible with a relatively simple criterion of selection as described above. More precise selection indices, including information on relatives (Schinckel, 1983), can be applied reasonably to a limited number of farms such as experimental or selection herds but this reduces the selection intensity.

(e) Extreme prolific sows generally present a disadvantage for production traits due to their age in selection herds or to the fact that they come from multipliers or producers. Consequently, systematic performance testing in favour of fast growth and low backfat thickness is highly recommended for boars and gilts of the strain.

\section{Other aspects connected with selection of extreme individuals}

Several studies indicate that the service boar affects the litter size of his mates, both in artificial

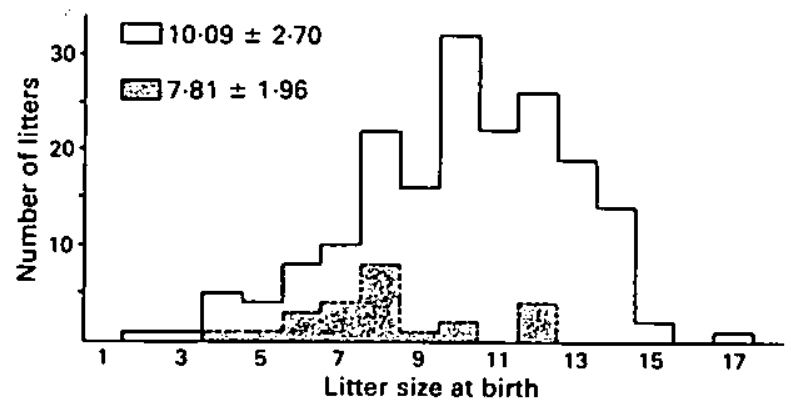

Fig. 5. Sizes of litters sired by two boars with $\left(5^{-}, 14^{+}\right)$translocations compared with contemporary litters (data from Popescu et al., 1984). 
insemination (Ollivier \& Legault, 1967) and in natural service conditions (Uzu, 1979). This probably occurs through the effect of viability genes transmitted to the embryos. A particularly striking example of such an effect is given by chromosomal abnormalities, particularly reciprocal translocations. A boar carrying a chromosomal translocation can reduce litter size of its mates in the range 5-50\% and also transmit its abnormality to half of its progeny. In a recent review, Popescu et al. (1984) list about 20 different reciprocal translocations described in the literature. Figure 5 shows a translocation reducing litter size by $22 \%$ and abnormalities with a moderate effect are generally more difficult to eliminate from the population. This is because young females raised in small litters have a selection advantage due to a better appearance and also due to a possible maternal effect on prolificacy (Robison, 1981). Computerized field recording systems to select prolific animals can also be an aid for detecting males or females of very low prolificacy.

As mentioned above, major genes affecting prolificacy generally have an unfavourable effect (Cardent, Hill \& Webb, 1985). Renard, Bolet, Dando \& Vaiman (1985) have identified a possible role of the pig major histocompatibility complex suspected to increase embryonic mortality. A search for major genes with a favourable effect on litter size would be extremely helpful.

\section{Discussion}

The present review indicates that large litters of pigs can result either from the combination of a normal ovulation rate with a low embryo mortality (e.g. the Meishan breed and crossbred females in general) or from the combination of high ovulation and embryo mortality (in the case of extremely prolific Western sows). Conversely, increasing ovulation rate either through direct selection (Cunningham, England, Young \& Zimmerman, 1979) or through superovulation (see Polge, 1982, for a review) does not seem to improve litter size at farrowing. The success of a combined selection for ovulation rate and embryo survival is compromised by the very low heritability of the second trait and the non-linear relationship between these two litter size components. A more promising way would be to evaluate the large genetic variability among pig populations throughout the world and to detect breeds, strains or their crosses characterized by both a high ovulation rate and a high embryo survival. On the other hand, the result of crossbreeding maintained constant in classical conditions could be enhanced either by a consistent increase in the genetic level of one of the parental lines (as with the 'hyperprolific' strain or with Chinese breeds) or by a search for exceptional combining abilities between breeds resulting in a high heterosis effect (the situation illustrated by the Jiaxing $\times$ Large White cross).

The object is to optimize the use of the best pig breeds or strains, keeping in mind the necessity of maintaining an economic balance between reproduction and production traits. Moreover, genetic variability must be saved to permit further progress through selection.

Taking advantage of the existing prolific breeds and of the possibility of pooling extreme animals within specialized strains, it is possible to suggest different solutions to break the apparent 'genetic plateau' for prolificacy.

\section{Three-way terminal crossbreeding scheme including a Chinese breed (Fig. 6a)}

This method consists of producing $F_{1}$ females resulting from the cross between a Chinese breed (for example of the Taihu group) and a Western breed of the 'dual-purpose' type and then to use a highly specialized boar for the terminal cross. If the absence of any difference in the prolificacy of sows from the 2 reciprocal crosses is confirmed, it would be preferable to use the Chinese breed as the maternal line of line first cross. This would lead to a lower production cost of the $F_{1}$ female and also to the use of Western boars highly selected for production traits. In fact because of an early and active puberty (at 2-3 months of age), performance testing of young Chinese boars appears to be 
(a) 3-way terminal cross

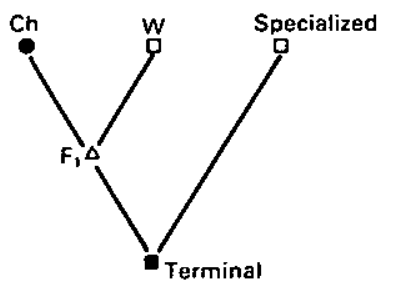

(b) I-way terminal cross

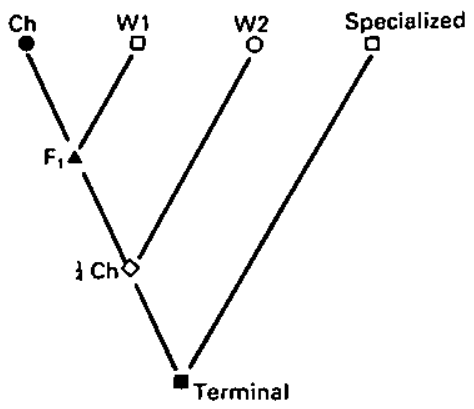

(c) Composite line selected for production traits
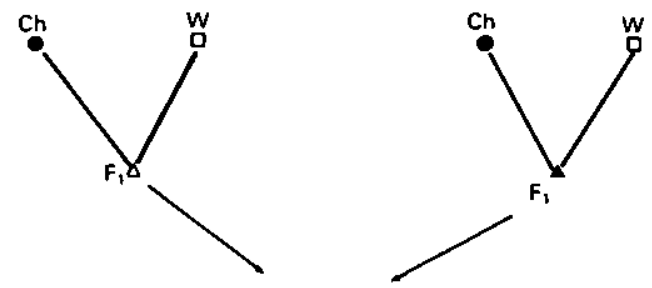

$$
\begin{gathered}
F_{2} \times F_{2} \\
i \\
F_{3} \times F_{3} \\
1
\end{gathered}
$$

Fig. 6. Crossbreeding schemes (3-way and 4-way) and a composite strain scheme using Western (W) and Chinese $(\mathrm{Ch})$ breeds of pigs.

difficult. Moreover, using a 3-way terminal crossbreeding scheme maximizes maternal and individual heterosis and exploits the complementary characteristics of sire and dam lines.

\section{Four-way terminal crossbreeding system including a Chinese breed (Fig. 6b)}

This method, derived from the previous one, consists of producing ' $25 \%$ Chinese' females to be mated to specialized terminal boars. Using Chinese females in the first cross, it is then possible to utilize successively highly selected boars for production traits from 2 Western breeds of the 'dual-purpose' type (Danish Landrace and Large White for example). It may also be suggested that boars of the hyperprolific strain described above are used for the second cross. Possible recombination losses could be balanced by using successively two breeds of boars of which one may belong to a prolific strain.

\section{Composite line including Chinese and Western breeds (Fig. 6c)}

Another solution could be the maintenance of the high prolificacy of Chinese $\times$ Western $F_{1}$ sows (13-14 pigs per litter) within a composite line selected in favour of heritable production traits such as growth rate and backfat thickness. An important genetic gain due to selection within a new population derived from a crossbred foundation could be obtained. However, the heterosis effect 
can be reduced by half compared with the $F_{1}$, and recombination losses could also modify performance in subsequent generations. On the other hand, apart from the specific case of unfavourable major genes such as that of halothane sensitivity, reproduction and production traits seem to be genetically independent (see Hill \& Webb, 1982; Legault, 1983, for reviews). Combining a prolific Chinese breed and a 'hyperprolific' strain in the crossbred foundation is another promising solution which should be tested.

\section{Further utilization of 'hyperprolific' strains}

We have seen above that developing a prolific strain by selecting extreme individuals within a population gives a gain limited to about 1 pig per litter. Extremely prolific animals can also be used as a foundation for the development of a 'gene pool' submitted to selection in favour of this trait, as illustrated by the Australian experiment. All these methods could also be efficiently improved by a search for major genes favourable to reproduction.

In conclusion, recent genetic developments indicate that we can be optimistic about the possibility of increasing litter size and consequently the numerical productivity of sows in the near future. The choice between the different solutions discussed above depends on the economic balance between production and reproduction, particularly in the use of Chinese breeds. Finally, 30 piglets weaned per sow and per year can be proposed for the top pig farmers as a realistic objective for 1995.

I thank M. Bichard of the Pig Improvement Company, and my colleagues G. Bolet, J. C. Caritez, J. Gruand and F. Martinat-Botte for their help and permission to use unpublished data in this review.

\section{References}

Aumaitre, A., Morvan, C., Quere, J.P., Peiniau, J. \& Vallet, G. (1982) Productivite potentielle et reproduction hivernale chez la laie (sus scrofa) en milieu sauvage. Journées Rech. porcine en France 14, 109-124.

Bichard, M. \& David, P.J. (1985) Effectiveness of genetic sclection for prolificacy in pigs. J. Reprod. Fert., Suppl. 33, 127-138.

Bolet, G. (1985) Timing and extent of embryonic mortality in pigs, sheep and goats. Genetic variability. In Currem Topics in Veterinary Medicine and Animal Science (European Economic Community Seminar). (In press.)

Bolet, G. \& Legault, C. (1982) New considerations on genetic improvement of prolificacy in the pig. Proc. 2nd Wld Congr. Genetics applied to Livestock Production, Madrid 5, 548-567.

Cardent, A.E., Hill, W.G. \& Webb, A.J. (1985) The effects of halothane susceptibility on some economically important traits in pigs. Anim. Prod. 40, $351-358$.

Cheng, P.L. (1983) A highly prolific breed of China-the Taihu Pig. Pig News and Information 4, 407-425.

Cunningham, P.J., England, M.E., Young, L.D. \& Zimmerman, D.R. (1979) Selection for ovulation rate in swine: correlated response in litter size and weight. J. Anim. Sci. 48, 509-5i6.

Dickerson, G. (1969) Experimental approaches in utilizing breed resources. Anim. Breed. Abstr. 37, 191-202.

Epstein, H. (1969) Domestic Animals of China. Commonwealth Agricultural Bureaux, Edinburgh.
Gianola, D., Legault, C. \& Caritez, J.C. (1982) Evaluation of Chinese swine germ-plasm in France. Proc. Pork Industry Confer. Urbana pp. 39-55.

Hill, W.G. \& Webb, J.A. (1982) Genetics of reproduction in the pig. In Control of Pig Reproduction, pp. 541564. Eds D. J. A. Cole \& G. R. Foxcroft. Butterworths, London.

Johansson, K. (1981) Some notes concerning the genetic possibilities of improving sow fertility. Livest. Prod. Sci. 8, $431-447$.

Johnson, R.K. (1981) Crossbreeding in swine: experimental results. J. Anim. Sci. 52, 906-923.

Legault, C. (1978) Particularites zootechniques des porcs eleves en Republique populaire de Chine. Bull. Tech. Inf. (327), 115-125.

Legault, C. (1983) Breeding for larger litters in swine. Prod. Pork Industry Conf., Urbana pp. 1-26.

Legault, C. \& Caritez, J.C. (1983) L'experimentation sur le porc Chinois en France: I. Performances de reproduction en race pure et an croisement. Genet. Sel. Evol. 15, 225-240.

Legault, C. \& Gruand, J. (1976) Amelioration de le prolificité des Truies par la creation d'une lignee 'hyperprolifique' et l'usage de l'insemination artificielle: principe et resultats experimentaux preliminaires. Journées Rech. porcine en France 8, 201-212.

Legault, C. \& Gruand, J. (1981) Effets additifs et nonadditifs des gènes sur la precocité sexuelle, le taux d'ovulation et la mortalité embryonnaire chez le jeune truie. Journées Rech. porcine en France 13, 247-254. 
Legault, C., Molenat, M., Steier, G., Texier, C. \& Zickler, G. (1974) Principle and illustration of a computerized sow field recording system. Journées Rech. porcine en France 6, 11-17.

Legault, C., Gruand, J. \& Bolet, G. (1981) Résultats de l'utilisation en race pure et en croisement de la lignée dite 'hyperprolifique'. Journees Rech. porcine en France 13, 255-260.

Legault, C., Caritez, J.C., Gruand, J. \& Bidanel, J.P. (1984) Le point de l'experimentation sur les races chinoises en France: 'reproduction' et 'production'. Journées Rech. porcine en France 16, $481-494$.

Legault, C., Sellier, P., Caritez, J.C., Dando, P. \& Gruand, J. (1985) Experimentation sur le Porc Chinois en France. II. Performances de production en croisement avec les races européenes. Genet., Sel. Evol. 17, 133-152.

Mason, I.L. (1969) A World Dictionary of Livestock Breeds, Types and Varieties, 2nd edn, pp. 149-177. Commonwealth Agricultural Bureau, Edinburgh.

Moav, R. \& Hill, W.G. (1966) Specialized sire and dam lines. IV. Selection within lines. Anim. Prod. 8, 375-390.

Noguera, J.L. \& Legault, C. (1984) Trends in productivity of sows during the last ten years in France. Pig News and Information 5, 205-21 2.

Ollivier, L. (1982) Selection for prolificacy in the pig. Pig New's and Information 3, 383-388.

Ollivier, L. \& Bolet, G. (1981) La selection sur la prolificité chez le porc: resultats d'une experience de selection sur dix generations. Journées Rech, porcine en France 13, 261-268.

Ollivier, L. \& Legault, C. (1967) L'influence directe du verrat sur la taille et les poids des portees obtenues par insemination artificielle. Ann/s Zootech. 16, 247-254.

Olliver, L. \& Sellier, P. (1982) Pig genetics: a review. Annls Genet. sel. anim. 14,481-544.

Phillips, R.W. \& Hsu, T.Y. (1944) Chinese swine and their performance compared with modern and crosses between Chinese and modern breeds. J. Hered. 35, 365-379.

Polge, C. (1982) Embryo transplantation and preservation. In Control of Pig Reproduction, pp. 277-292. Eds D. J. A. Cole \& G. R. Foxcroft. Butterworths, London.

Popescu, C.P., Bonneau, M., Tixier, M., Barhi, I. \& Boscher, J. (1984) Reciprocal translocations in pigs: their detection and consequences on animal performance and economic losses. J. Hered. 75, $448-452$.
Renard, C., Bolet, G., Dando, P. \& Vaiman, M. (1985) Influence of a genetic marker (the S.L.A. system) on prolificacy and embryonic mortality. Journées Rech. porcine en France 17, 105-112.

Robison, O.W. (1981) The influence of maternal effects on the efficiency of selection: a review. Livest. Prod. Sci. 8, 121-137.

Rombauts, P., Mazzari, G. \& du Mesnil du Buisson, F. (1982) Premier bilan de l'experimentation sur le porc Chinois en France. 2. Estimation de composantes de la prolificité: taux d'ovulation et survic foetale. Journées Rech. porcine en France 14, 137-142.

Schinckel, A. (1983) Estimated breeding values for swine improvement. Proc. National Swine Improvement Federation 8, 73-80.

Sellier, P. (1976) The basis of crossbreeding in pigs; a review. Livest. Prod. Sci. 3, 203-226.

Sellier, P. (1982) Le choix de la lignée male du croisement terminal chez le porc. Journees Rech. porcine en France 14, 159-182.

Skjervold, H. (1979) What about the genetic improvement of litter size? Acta agric. scand., Suppl. 21, 176-184.

Sutherland, R.A., Webb, A.J. \& King, J.W.B. (1985) A survey of world pig breeds and comparisons. Anim. Breed. Absir. 53, 1-22.

Tomes, G.J. \& Newman, R.B. (1984) Selection for litter size in pigs. Proc. Ausir. Soc. Anim. Prod. 15, 760, Abstr.

Tomes, G.J. \& Nielsen, H.E. (1985) Some aspects of selection for increased reproductive performance in sow herds. Anim. Breed. Abstr. 53, 1494, Abstr.

Uzu, G. (1979) Influence du verrat sur les principaux paramètres de la productivitè du troupeau et sur la durée de gestation. Annls Zootech. 28, 315-323.

van der Steen, H.A.M. (1983) Maternal and genetic infuences on production and reproduction traits in pigs. Doctoral thesis, Agricultural University, Wageningen.

Vangen, O. (1981) Problems and possibilities for selection for fecundity in multiparous species. Pig News and Information 2, 257-263.

Young, L.D., Johnson, R.K. \& Omtvedt, I.T. (1976) Reproductive performance of swine bred to produce purebred and two-breed cross litters. J. Anim. Sci. 42, Il 33-I 149.

Zhang, W.C., Wu, J.S. \& Rempel, W.E. (1983) Some performance characteristics of prolific breeds of pigs in China. Livest. Prod. Sci. 10, 59-68.

Zheng, Z.G. (1981) The pig breed resources of China: a perspective. Natural Resources, China 2, 65-71. 